Research Article

\title{
The Use of Natural Phenomenon in Obtaining Pregnant Rats and Mice as Experimental Animals with The Same Gestational Ages
}

\author{
Teguh Wahju Sardjono ${ }^{1 *}$, Harry Kurniawan Gondo ${ }^{2}$, Rivo Yudhinata Brian Nugraha ${ }^{1}$, Anisa Tiara \\ Putri $^{3}$, Meyland Citra Oktri Sienty Effendy ${ }^{3}$ \\ ${ }^{1}$ Department of Parasitology, Faculty of Medicine Universitas Brawijaya, Malang 65145, Indonesia \\ ${ }^{2}$ Department of Obstetry and Gynecology, Faculty of Medicine Wijayakusuma University, Surabaya 60225, \\ Indonesia \\ ${ }^{3}$ Faculty of Medicine, Universitas Brawijaya, Malang 65145, Indonesia
}

Article history:

Submission May 2019

Revised August 2019

Accepted September 2019

*Corresponding author:

E-mail:

teguhws@ub.ac.id

\begin{abstract}
Hormonal oestrus synchronization is often used to obtain the same gestational ages animal models, but it may not physiologic nor practical. This research was conducted to find out a simple method in obtaining physiologic pregnant experimental animals. We used 120 female rats and mice each, divided into 16 groups with 15 members each. They were classified according to the state of parities, pair or group mating, and synchronization of oestrous. The estrous synchronization is done by utilizing the natural phenomenon (Lee-Boot, Pheromone, and Whitten effect). All nulliparous and multiparous models then were simultaneously mated for one night in pairs (1:1) or in groups (1:5) subsequently. Pregnancy rates were noted based on the number of models delivering pups on day 19-23 post-mating. The highest pregnancy rate was noted in group of multiparous, synchronized and monogamous rats (86.7\%), followed by nulliparous, synchronized and monogamous rats (73.3\%) and multiparous, synchronized and monogamous mice $(60 \%)$ $(p<0.05)$. Synchronization of the estrous and monogamous mating of rats or mice had significant roles in pregnancy rates $(\mathrm{p}<0.05)$. To get a high number of pregnant rats or mice models, we suggest using the multiparous, estrous synchronized and monogamous simultaneous mating within one night.
\end{abstract}

Keywords: Rats, mice, pregnant animal models, oestrus synchronization, LeeBoot Effect

\section{Introduction}

In biomedical research, the use of experimental animals has given important contributions in developing new concepts and pathogenesis of many diseases. By biomedical researches people had got more effective methods for diagnosing, preventing, and treating diseases, both in humans and animals. Animal models played role as semifinal test tubes before using human subjects. One target of using animals in biomedical research is that the animals are surrogate for human beings $[1,2,3,4]$. In facts human biology is very much like that of many other animals. In contrast, laboratory animals also have the same set of organs that work in the same way as they do in humans $[4,5]$.

In many researches, especially in experimental research using animal subjects, to ensure the precision and validity of data, and also the high statistical power, besides the sample size, the homogeneity of samples is also the main requirement that should be met [6]. In reproductive experimental studies, such as eclampsia, low birth weights and many other pregnancy disorders, pregnant animal models with the same gestational ages are absolutely needed. To have a certain number of homogenous animal models, simultaneously mating of the animals is needed. However, once mating is not always reaching the expected

\section{How to cite:}

Sardjono TW, Gondo HK, Nugraha RYB et al. (2019) The Use of Natural Phenomenon in Obtaining Pregnant Rats and Mice as Experimental Animals with The Same Gestational Ages. Journal of Tropical Life Science 9 (3): 229 - 235. doi: 
number of pregnant animals needed. When we mated a number of animals, not all of the females then become pregnant. The pregnancy rate is often unpredictable, or maybe very low. The main cause of the low pregnancy rate is, when the females mated, they might be not in oestrus condition so that the fertilization failed. Unfortunately, the successful or the failure of pregnancy both is difficult to be predicted and detected in the early stage of gestational period. The presence of vaginal plug only indicates that copulation has taken place, and does not guarantee that the female is pregnant [16, $17,18]$, as well as the increase of body weights. If the number of pregnant samples required in the research is low or insufficient, it will affect the validity of data and results. Therefore, to reach the pregnancy rates for the target number of samples needed, before the females are mated simultaneously, their oestrus cycles should be synchronized first.

There are many methods of oestrus synchronization to increase the success of pregnancy. Hormonal synchronization of ovulation is the process by which the reproductive cycle of an animal is manipulated by using hormones or their analogs to induce ovulation at a precise point in time [7]. The use of artificial hormones had been widely used, especially in livestock industries; such as prostaglandin 2/PGF2 and some progesterone derivatives in goats [8,9], or various combinations with other hormones such as oestrogen and gonadotrophin, releasing hormone (GnRH) in cattle [10]. Although hormonal synchronization of oestrus may useful in livestock industries, but in experimental reproductive researches it may affect the values of chemical substance(s) and some characteristics which serve as variable(s) in the research $[11,12]$. Therefore, natural oestrus synchronization by not utilizing hormonal substances hopefully will result more physiologic conditions of pregnant animal models.

Almost $80 \%$ of the experimental animals are rodents including mice, rats and guinea pigs, then followed by rabbits, dogs, cats, swine, goats, bulls and some species of primates. Rats and mice have many advantages compared to other animals. Beside their similarities of organ structure, anatomy and physiology; correlation of the life span between human and rat or mice (one human year almost equals two weeks' rat), and the only 20 to 23 days' gestational period they have, making their gestational process is much easily observed [13, $14,15,16,17]$. Therefore, in various biomedical researches, especially reproductive researches, rats and mice are the most often used as experimental animals.

Female rats and mice are poly-oestrous. They come into heat every $4-5$ days $[15,16,17]$. There are specific natural phenomenons found in rodents, those are: 1). Housing of females with the only females in groups and separated from the males for certain period, will suppress the female's oestrous cycle, and the females become unoestrous (Lee Boot Effect). 2). Adding male's urine (or dirty bedding from a male's cage) to the females' cage will restart the oestrous cycle (Pheromone effect), and 3) within 3 days or about 72 hours after exposure the females then becoming oestrous (Whttten Effect). These natural phenomenons are useful to be utilized for obtaining a group of females with the same oestrous condition. Generally, if we put in a male into the cage for one night, at least $75 \%$ of the females will become pregnant $[16,17,18,19]$.

This study was conducted in order to promote a simple and practical method in obtaining certain number of targeted physiologic pregnant animal models by synchronizing of oestrous cycle and utilizing natural phenonemons (Lee Boot, Pheromone and Whitten effects).

\section{Material and Methods \\ Plant material}

This experimental cohort study consisted of two parts of studies, those were study on rats and mice respectively. The study used totally 240 female animals, consisted of 60 virgin female rats (Rattus norvegicus- Wistar strain) aged 10-12 weeks old, 150-200 g weight, and 60 virgin female Balb/c mice aged 10-12 weeks, 20-30 grams weights. They were served as nulliparous groups. The next study used 60 rats and 60 mice which had an experience of pregnant. They were served as multiparous groups. All of the female rats and mice models and also the males used as studs were obtained from the Faculty of Pharmacy, Universitas Gadjah Mada, Yogyakarta, Indonesia.

In the first study, the first 30 nulliparous female rats and 30 nulliparous female mice were divided into two groups. Before the 15 rats and 15 mice were mated monogamously and in group respectively, they were isolated and housed with the 


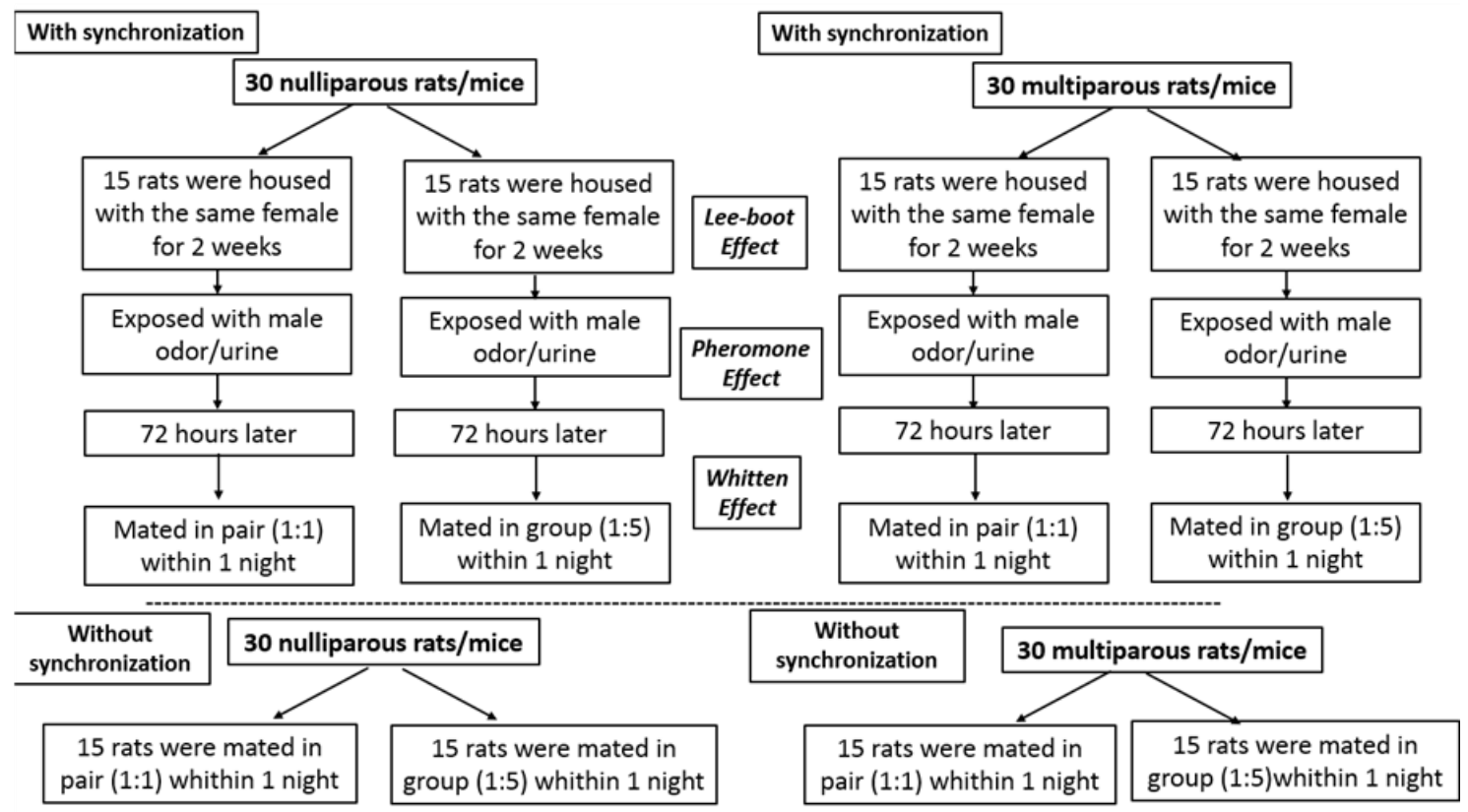

Figure 1. Flow chart of study

same females for two weeks to get the Lee-Boot effect. After that they were exposed with dirty bedding from a male's cages to get the Pheromone effect. Seventy-two hours after the exposure with male's odours, the females were being in oestrous (Whitten effect). We then put the stud males in each 15 cages of pairs (1:1) and 3 cages of groups (1:5) over night. The other 30 rats and 30 mice were also mated by the same ways, those were in pairs (1:1) and in groups (1:5) for one night, but without synchronization. The non-synchronized rats/mice were used as comparison groups. The males then were taken out from the cages after overnight of mating, and then let the females still in their own cages until day 19-23 or they delivered pups or not. The number of rats/mice which delivered pups or not which observed until day 24 post mating were noted. The next study was performed by using 60 multiparous rats and 60 multiparous mice, with the same procedure of grouping and treatments as well. The flowchart of study is showed on (Figure 1).

Statistical analysis was observed by comparing the differences of pregnancy rates then were statistically analysed using SPSS-21 software, by Chi-square test with 95\% confidence interval. Proposal of this study had been approved by the Ethical Committee of Health Research Faculty of Medicine Universitas Brawijaya.

\section{Results and Discussion}

Pregnancy rates of total of 120 rats and 120 mice in this study, which consisted of 8 groups and 15 rats or mice in each group are shown in Table 1. The highest pregnancy rate of rats found in group 3 (synchronized, multiparous, monogamous $=86.7 \%$ ), followed by the group 1 (synchronized, nulliparous, monogamous $=77.3 \%$ ). The lowest pregnancy rate in rats is found in group 6 (nonsynchronized, nulliparous, polygamous $=6.7 \%$ ). On the other hand, the highest pregnancy rate in mice is found in group 3 (synchronized, multiparous, monogamous $=60 \%$ ) then followed by group 7/ non-synchronized, multiparous, monogamous (53.3\%). The lowest pregnancy rate in mice found in group 2 (synchronized, nulliparous, polygamous $=13.3 \%)$.

Table 2 shows that in rats, statistical analysis (Chi square test with 95\% Confidence Interval) found significant differences between different treatments of synchronization $(\mathrm{p}=0.040$; $\mathrm{RR}$ $1,45)$ and the way of mating $(p=0.000 ; R R=$ 2.88), but not for the parity status ( $\mathrm{p}=0.575$; $\mathrm{RR}$ $=1.11)$. Among the 8 groups of mice, the highest of pregnancy rate also found in group 3 (60.0\%) and followed by the group 7 (53.3\%). The Chi square statistical analysis (Table 3) shows that in mice, the significant differences were only found in parity status $(\mathrm{p}=0.001 ; \mathrm{RR}=1.80)$ but not for 
TW Sardjono, HK Gondo, RYB Nugraha, 2019 / Natural Animal Models with Same Gestational Ages

Figure 1. Flow chart of study

\begin{tabular}{lcccccccc}
\hline \multirow{2}{*}{ Group } & \multicolumn{3}{c}{ RATS } & \multicolumn{3}{c}{ MICE } \\
\cline { 2 - 9 } & Total & Pregnant & Unpregnant & Rate & Total & Pregnant & Unpregnant & Rate \\
\hline 1 (snm) & 15 & 11 & 4 & 73.3 & 15 & 4 & 11 & 26.7 \\
2 (snp) & 15 & 3 & 12 & 20 & 15 & 2 & 13 & $\mathbf{1 3 . 3}$ \\
3 (smm) & 15 & 13 & 2 & $\mathbf{8 6 . 7}$ & 15 & 9 & 6 & $\mathbf{6 0}$ \\
4 (smp) & 15 & 2 & 13 & 13.3 & 15 & 6 & 9 & 40 \\
5 (nnm) & 15 & 7 & 8 & 46,7 & 15 & 3 & 12 & 20 \\
6 (nnp) & 15 & 1 & 14 & $\mathbf{6 . 7}$ & 15 & 3 & 12 & 20 \\
7 (nmm) & 15 & 8 & 7 & 53.3 & 15 & 8 & 7 & 53.3 \\
8 (nmp) & 15 & 2 & 13 & 13.3 & 15 & 6 & 9 & 40 \\
\hline Total & 120 & 47 & 73 & 39.17 & 120 & 41 & 79 & 34,17 \\
\hline
\end{tabular}

Note: Group 1 (snm) : synchronized, nulliparous, monogamous

Group 2 (snp) : synchronized, nulliparous, polygamous

Group 3 (smm) : synchronized, multiparous, monogamous

Group 4 (smp) : synchronized, multiparous, polygamous

Group 5 (nnm) : non-synchronized, nulliparous, monogamous

Group 6 (nnp) : non-synchronized, nulliparous, polygamous

Group 7 (nmm) : non-synchronized, multiparous, monogamous

synchronization $(\mathrm{p}=0.847 ; \mathrm{RR}=1.04)$ and the way of mating ( $\mathrm{p}=0.178$; $\mathrm{RR}=1.28)$.

In reproductive researches, especially in obtaining pregnant experimental animals, estimating number of animals that should be prepared to have the minimum targeted number of samples required, is the most problem. It because of estimating the successful of pregnancy are not always easy. In the early phases of pregnancy or during the frost to second week after mating, the pregnancy states are often difficult to be predicted by physical performance only, such as the increase of body weights. There are many factors influencing successful of pregnancy, such as species, strain, age, nutritional status, parity states, environmental hygiene, humidity, temperature, level of noisy, and also the time and the way of mating $[15,16$, $17,18]$. Synchronization of oestrus is an important step in getting a number of pregnant experimental animals with the same gestational ages. There are many methods known and then used for stimulating or regulating oestrus cycles. The most often and widely used is hormonal method, by using certain synthetic reproductive hormone derivatives, such as progesterone, oestrogen, prostaglandin F2 $\alpha$ and gonadotropin releasing hormones $[7,8,9$, 10]. Those hormonal methods might be useful in livestock or husbandry industry, but in reproductive researches which focused on the pathogenesis of disease or other pathologic process during pregnancy, the use of hormonal substances for stimulating oestrus cycle may influence the validity of data, and therefore may be interfering the thinking process during interpreting results of the study.

Table 1 above showed that the pregnancy rate of rats in group 3 (86.7\%) and group 1 (77.3\%) are higher than other groups. Rats which mated in pair without synchronization, both for multi and nullipara are still having relatively high pregnancy rates ( $46.7 \%$ and $53.3 \%$ respectively), and the total pregnancy rate is $39.17 \%$. It means that if we mate the rats simultaneously in any conditions, the possibility to get pregnant animal is still about $40 \%$. In contrast, in mice there were only multiparous mated in pair with synchronization (group 3) and without synchronization (group 7) showed the higher pregnancy rate compared to other groups (60\% and $53.33 \%$ respectively). Statistical analysis results in Table 2 showed that in rats, synchronization of oestrus, and the technique of mating, are having significant impacts in pregnancy rate ( $\mathrm{p}$ $<0.05$ ), but not for the parity status ( $p>0.05)$. It means that in rats, by mating them either in pair or in group, with or without synchronization, nullipara or multipara, the pregnancy rates are more than $50 \%$ or still relatively high. But mating the rats in pairs have chance to get pregnant more than in groups $(\mathrm{RR}=2.88)$. In contrast in mice, parity 
Table 2. Analysis of difference of rat's pregnancy rate after over-night mating

\begin{tabular}{lcccccc}
\hline & \multicolumn{5}{c}{ Treatments } \\
\cline { 2 - 7 } Pregnancy Status & $\begin{array}{c}\text { Synchro- } \\
\text { nized }\end{array}$ & $\begin{array}{c}\text { Non- } \\
\text { Synchro- } \\
\text { nized }\end{array}$ & Multiparous & Nulliparous & $\begin{array}{c}\text { Monogamy } \\
(1: 1)\end{array}$ & $\begin{array}{c}\text { Poligamy } \\
(1: 5)\end{array}$ \\
\cline { 4 - 7 } Pregnant & 29 & 18 & 25 & 22 & 39 & 8 \\
Unpregnant & 31 & 42 & 35 & 38 & 21 & 52 \\
\hline P-value & & $0.040^{\mathrm{b}}$ & & 0.575 & $0.000^{\mathrm{b}}$ \\
\hline RR & 1.45 & & 1.11 & 2.88 \\
\hline
\end{tabular}

Table 3. Analysis of difference of mice pregnancy rate after over-night mating

\begin{tabular}{|c|c|c|c|c|c|c|}
\hline \multirow{3}{*}{ Pregnancy Status } & \multicolumn{6}{|c|}{ Treatments } \\
\hline & \multirow[b]{2}{*}{$\begin{array}{l}\text { Synchro- } \\
\text { nized }\end{array}$} & \multirow{2}{*}{$\begin{array}{l}\text { Non- } \\
\text { Synchro- } \\
\text { nized }\end{array}$} & \multicolumn{2}{|c|}{ Parity states } & \multicolumn{2}{|c|}{ Mating } \\
\hline & & & Multiparous & Nulliparous & $\begin{array}{c}\text { Monogamy } \\
(1: 1)\end{array}$ & $\begin{array}{c}\text { Polygamy } \\
(1: 5)\end{array}$ \\
\hline Pregnant & 21 & 20 & 29 & 12 & 24 & 17 \\
\hline Unpregnant & 39 & 40 & 31 & 48 & 36 & 43 \\
\hline P-value ${ }^{a}$ & \multicolumn{2}{|c|}{0.847} & \multicolumn{2}{|c|}{$0.001^{\mathrm{b}}$} & \multicolumn{2}{|c|}{0.178} \\
\hline $\mathrm{RR}$ & \multicolumn{2}{|c|}{1.04} & \multicolumn{2}{|c|}{1.80} & \multicolumn{2}{|c|}{1.28} \\
\hline
\end{tabular}

$\underline{\text { Table 4. Factors influencing pregnancy rates in rats and mice }}$

\begin{tabular}{lccccccccc}
\hline & \multicolumn{1}{c}{ Animal Model } & \multicolumn{2}{c}{ Oestrus synchronization } & Parity states & \multicolumn{2}{c}{ Mating } \\
\cline { 2 - 10 } & Rat & Mice & $\begin{array}{c}\text { Synchro- } \\
\text { nized }\end{array}$ & $\begin{array}{c}\text { Non-syn- } \\
\text { chronized }\end{array}$ & Multi & Nulli & $\begin{array}{c}\text { Monogamy } \\
(1: 1)\end{array}$ & $\begin{array}{c}\text { Poly gamy } \\
(1: 5)\end{array}$ \\
\hline Pregnant & 47 & 41 & 50 & 38 & 54 & 34 & 63 & 25 \\
Unpregnant & 73 & 79 & 70 & 82 & 66 & 86 & 57 & 95 \\
\hline P-value & \multicolumn{2}{c}{0.422} & & 0.108 & $0.007^{\mathrm{b}}$ & $0.000^{\mathrm{b}}$ \\
\hline
\end{tabular}

status is a factor that influencing pregnancy rate (p $<0.05$; RR $=1.80$;). Although synchronization of oestrous and monogamous mating seemed to be influencing the pregnancy rates, but statistically is not significant $(\mathrm{p}>0.05$. RR 1.04 and 1.28 respectively. Table 3). The difference of pregnancy rate in rats (39.17\%) and in mice (34.17\%) is not significant $(\mathrm{p}=0.422 ; \mathrm{RR}=1.11)$, means that using rats or mice has same advantages, depends on the type of research.

Naturally, rats are very easy to breed, much easier than mice. Rats can reach sexual maturity at five weeks of age and do not recognize incest, so brothers and sisters and even mothers and sons must be separated. In contrast, mice are getting mature around 8-12 weeks. and are not done growing until they are between 3 and 5 months of age, depending on the line $[16,17,18,19]$. This finding is supported by some previous studies. Sardjono (2005) reported that nulliparous mice which mated in groups without synchronization, resulted pregnancy rates only $7 / 80$ (8.75\%) and 11/120 (9.16\%) respectively. The next step, he used multiparous mice which were synchronized by utilizing the natural phenomenons, then followed by mating for one night in pair, the pregnancy rate was $45 / 80$ or $56.25 \%$ [20]. This study showed that in mice the parity status, synchronization of oestrous and mo- 
nogamous mating are important factors to be considered in obtaining pregnant animals. This study showed that in estimating number of pregnant rodents needed as animal models, the rats (Rattus norvegicus-Wistar strain) seemed to be more promising to be used rather than mice (Mus musculus), but statistically is not significant ( $\mathrm{p}>0.05$, Table 4). The results of this study could be used as a guide for estimating number of rats or mice which should be mated to get a number of samples needed for your research. As the highest pregnancy rate of rat is $86.7 \%$ and the mice is $60.0 \%$, so that if your research needs 30 pregnant rats, at least you should mate 100/86.7 $\times 30=35$ female rats, and if your research needs 30 mice, you should prepare $100 / 60 \times 30=50$ female mice or more.

This study was used 5 female rats and mice for group mating. Group/harem breeding is defined as the mating of one male with several female rats or mice. Previous studies have stated the recommended number for optimal pregnancy rates. It can be trio ( 2 female), up to 4 females in a cage [21], and also 5 females in a cage [15].

\section{Conclusion}

This study suggested that rats and mice both are having similar advantages to be used as pregnant experimental animals, depend on the types and the needs of research. In order to get a high number of pregnant animal models with simultaneous mating, it is suggested to use the multiparous rats or mice, with oestrus synchronization, and monogamous mating.

\section{Acknowledgment}

We acknowledge to Mr. Wahyu Pradana, technician from Faculty of Medicine, Wijayakusuma University and Mr. Budi Siswanto technician from Faculty of Medicine Universitas Brawijaya, for their assists in breeding and maintaining the rats and mice. This research was granted by the Institute for Research and Community Service (Lembaga Penelitian dan Pengabdian Masyarakat/LPPM) Faculty of Medicine Universitas Brawijaya Malang.

\section{References}

1. Franco NH (2013) Animal Experiments in Biomedical Research: A Historical Perspective. Animals 3 (1): 238 - 273. doi: 10.3390/ani3010238.
2. McLeod C, Hartley S (2017) Resposibility and laboratory animal research govenrnance. Science, Technology \& Human Values $\mathrm{XX}(\mathrm{X})$ : 1-19.

3. Giridaran NV, Kumar V (2000) Use of animal in scientific research. indian council of medical research. New Delhi, Ministry of Health and Family Welfare. Pp. 1-27.

4. Morgan CJ, Elangbam CS, Berens S et al. (2013) Use of animal models of human disease for nonclinical safety assessment of novel pharmaceuticals. Toxicologic Pathology 41 (3): 508 518. doi: 10.1177/0192623312457273.

5. Biosecurity Victoria (2011) Guidelines for the ethical use of animals in research and teaching. Melbourne, Department of Primary Industries.

6. Glasow PA (2005) Fundamentals of Survey Research Methodology. Washington, Mitre Product. P.2.1 -2.3.

7. Sentilkumar K, Selvaraju M, Ezakial-Napolean R et al. (2016) Pattern of oestrus and fertility rate following synchronization of ovulation in tellicherry goats. International Journal of Science, Environment and Technology 5 (5): 3289 - 3296.

8. Badawi ME, Makawi SEA, Abdelghaafar RM, Ibrahim MT (2014) Effect of oestrous synchronization using PGF2 $\alpha$ on subsequent fertility of nubian goats (Capra hircus). Journal of Agricultural and Veterinary Sciences 15 (2): 45 - 52. doi: 10.5455/javar.2014.a10.

9. Omontese BO, Rekwot PI, Ate IU et al. (2016) An update on oestrus synchronisation of goats in Nigeria Asian Pacific Journal of Reproduction 5 (2): 96 - 101 . doi: 10.1016/j.apjr.2016.01.002.

10. Islam R (2011) Synchronization of estrus in cattle: A review Veterinary World 4 (3): 136 - 141.

11. Dhami AJ, Nakrani BB, Hadiya KK et al. (2015) Comparative efficacy of different estrus synchronization protocols on estrus induction response, fertility and plasma progesterone and biochemical profile in crossbred anestrus cows. Veterinary World 8 (11): 1310 - 1316. doi: 10.14202/vetworld.2015.1310-1316.

12. Sen U, Onder H (2016) The effect of estrus synchronization programmes on parturition time and some reproductive characteristics of Saanen goats. Journal of Applied Animal Research 44 (1): 376 - 379. doi: 10.1080/09712119.2015.1091348.

13. Andreollo NA, dos Santos EF, Araujo MR, Lopes LR (2012) Rat's age versus human's age: What is the relationship?. ABCD. Arquivos Brasileiros de Cirurgia Digestiva 25 (1): 49-51. doi: 10.1590/s0102-67202012000100011.

14. Sengupta P (2013) The Laboratory rat: Relating its age with human's. International Journal of Preventive Medicine 4 (6): 624 -630 .

15. Smith JB, Mangkoewidjojo S (1987) The Care breeding and management of experimental animals for research in the tropics. New York, International Development Program of Australian Universities and Colleges Limited (IDP). pp 36 - 38. 
16. Bogdanske JJ, Stella SHV, Riley MR, Schiffmann BM (2010) Laboratory mouse, procedural techniques manual and DVD. Boca Raton, Wisconsin Alumni Research Foundation, Laboratory CRC Press Taylor \& Francis Group.

17. Bogdanske JJ, Stella SHV, Riley MR, Schiffmann BM (2010) Laboratory rat procedural techniques manual and DVD. Boca Raton, Wisconsin Alumni Research Foundation, Laboratory CRC Press Taylor \& Francis Group.

18. Lambert R (2007) Breeding strategies for maintaining colonies of laboratory mice. A Jackson Resource Manual. Bar Harbor, The Jackson Laboratory.
19. Animal Care and Use Program (2013) Best practices for optimizing mouse breeding programs. Berkeley, University of California.

20. Sardjono TW (2005) Influence of toxoplasma infection on pregnancy outcome through gamma interferron (IFN- $\gamma$ ), activation of caspase- 3 and apoptosis of placental cells. PhD Thesis. Airlangga University.

21. Jimenez, A (2016) SOP \#608 mouse breeding colony management. Montreal, McGill Comparative Medicine \& Animal Resources Centre. 
This page is intentionally left blank. 